\title{
Importance of dam-free tributaries for conserving fish biodiversity in Neotropical reservoirs
}

\author{
Hugo Marques $^{\mathrm{a}, \mathrm{b}, *}$, João Henrique Pinheiro Dias ${ }^{\mathrm{c}}$, Gilmar Perbiche-Neves ${ }^{\mathrm{d}}$, \\ Elaine Antoniassi Luiz Kashiwaqui ${ }^{\mathrm{e}}$, Igor Paiva Ramos ${ }^{\mathrm{a}, \mathrm{b}, \mathrm{c}}$ \\ ${ }^{\text {a } U n i v e r s i d a d e ~ E s t a d u a l ~ P a u l i s t a ~(U N E S P), ~ C e n t r o ~ d e ~ A q u i c u l t u r a, ~ V i a ~ d e ~ A c e s s o ~ P r o f . ~ P a u l o ~ D o n a t o ~ C a s t e l l a n e, ~ 14884-900 ~ J a b o t i c a b a l, ~ S P, ~ B r a z i l ~}$ \\ ${ }^{\mathrm{b}}$ Universidade Estadual Paulista (UNESP), Instituto de Biociências, R. Prof. Dr. Antônio Celso Wagner Zanin, 250, 18618-689 Botucatu, SP, Brazil \\ ${ }^{\mathrm{c}}$ Universidade Estadual Paulista (UNESP), Faculdade de Engenharia, Rua Monção, 226, CEP: 15385-000 Ilha Solteira, SP, Brazil \\ ${ }^{\mathrm{d}}$ Universidade Federal de São Carlos, Campus Lagoa do Sino, Rodovia Lauri Simões de Barros, Km 12, CEP: 18290-000 Buri, SP, Brazil \\ e Universidade Estadual de Mato Grosso do Sul, Campus de Mundo Novo, MS, BR 163, km 20.2, CEP: 79980-000 Mundo Novo, MS, Brazil
}

A R T I C L E I N F O

\section{Keywords:}

Diversity

Impoundments

Long-term monitoring

Fish fauna

Tributaries

Homogenization

\begin{abstract}
A B S T R A C T
Dams change the hydrological dynamics, patterns of biological production and distribution of organisms in space and time. In contrast, tributary rivers can function as source areas in reservoirs, since they harbor spawning and early development grounds for native fish species. Here, we analyze a time series of the first 14 years after the impoundment of the Porto Primavera Reservoir, a large reservoir with free tributaries in southeastern Brazil. To evaluate the impact of damming on the fish assemblage, we evaluated the abundance (catch per unit effort, CPUE) and $\alpha$ (species richness and Shannon-Wiener index) and $\beta$ (Sørensen dissimilarity and turnover) diversity of four sites distributed along the reservoir. Overall, there was no decreasing trend in the $\alpha$ diversity and no increasing trend in the $\beta$ diversity relative to the initial year or among the sites over time. Despite the expected disturbance in the fish assemblage at the lacustrine site, the sites located near the tributary mouths presented resistant fish assemblages, compensating the results of the overall assessment. We attribute this unusual variation in the ecological attributes to source-sink demographic dynamics, with the undammed tributaries as the source and the reservoir as the sink for native species. We highlight that the presence of these rivers minimized the expected trend towards biotic homogenization, and the preservation of the tributaries is imperative since they contribute to diversity maintenance in areas that are already impacted by damming. The inclusion of this agenda in environmental management programs and new impoundment plans will allow a balance between the demand for electricity production and the conservation of fish diversity.
\end{abstract}

\section{Introduction}

The impoundment of rivers causes the homogenization of fluvial dynamics by decreasing the intensity of floods and droughts and the interannual variation of flow (Poff et al., 2007). Moreover, impoundments fragment habitats, decrease river connectivity (Nilsson et al., 2005), and reduce fish access to nursery and feeding grounds (Winemiller et al., 2016). This anthropic process represents one of the most drastic habitat changes (Agostinho et al., 2008; Agostinho et al., 2016), since it modifies the natural hydrological dynamics, limnological variables, biological productivity patterns and the distribution of organisms in space and time (Nilsson et al., 2005). Such effects dramatically change many aspects of the native fish fauna, resulting in consequences to the abundance and composition of native fish by the reduction of species richness (Agostinho et al., 2007; Agostinho et al.,
2008; Agostinho et al., 2016). This mainly affects migratory species, impeding them from being able to migrate and complete their life cycle (Agostinho et al., 2016; Winemiller et al., 2016). On the other hand, some opportunistic and sedentary species, with a short life cycle and generalist feeding habits, are favored under these conditions and can proliferate (Agostinho et al., 2008; Agostinho et al., 2016). Furthermore, impoundments increase the homogenization of aquatic biota (Rahel, 2002; Olden \& Poff, 2004; Vitule et al., 2009; Petesse \& Petrere Jr, 2012; Vitule et al., 2012). This results from the interaction of three processes: the introduction of nonnative species, the elimination of native species and habitat changes, which facilitates the two previously listed processes (Rahel, 2002).

Despite the impacts caused by human activities and the consequent loss of biological diversity (Magurran \& Dornelas, 2010), there is a trend of natural variation over time to a greater or lesser extent

\footnotetext{
* Corresponding author at: Universidade Estadual Paulista (UNESP), Instituto de Biociências, R. Prof. Dr. Antônio Celso Wagner Zanin, 250, $18618-689$ Botucatu, SP, Brazil.

E-mail address: hugo@fishtag.com.br (H. Marques).
} 
(Magurran et al., 2010; Magurran \& Dornelas, 2010; Magurran \& Henderson, 2010). This natural variation is important for community diversity maintenance (Magurran \& Henderson, 2010) and occurs according to the environmental conditions, which reflect ecological and evolutionary processes (Magurran \& Dornelas, 2010). Although it is well known that all ecological communities experience temporal variations, there is still little information about how these changes occur over time (Magurran \& Henderson, 2010). Therefore, the challenge is to distinguish changes caused by natural processes from the anthropic ones (Magurran et al., 2010).

In this sense, long-term monitoring is indispensable because it allows the understanding of temporal changes in biodiversity, thus enabling the detection and assessment of the anthropogenic impacts underlying these processes (Magurran et al., 2010). In impacted environments such as dammed rivers, long-term studies are necessary for the determination of the major factors that influence the faunal structure (Říha et al., 2009). These studies also can provide information about fish fauna responses to perturbations over time and are necessary for management conservation measures (Gido et al., 2000). Additionally, long-term data allow the verification of hypotheses related to ecological succession processes and diversity-stability relationships (Magurran et al., 2010; Mellin et al., 2014).

In metacommunity models, where a large number of migratory species occupy diversified habitats, structurally distinct communities could provide different responses to environmental variations, since negative fluctuations in one community could be compensated by positive fluctuations in another, increasing the resilience of the whole metacommunity (Mellin et al., 2014). A set of demographic dynamics in a source-sink model where populations living in spatially heterogeneous environments select habitats based on differences in the environmental quality (Pulliam, 1988) could accomplish this kind of process. In this way, recent studies have demonstrated that tributaries could function as source areas in reservoirs, since they harbor spawning and early development grounds for fish assemblages (da Silva et al., 2015; Nunes et al., 2015; Angulo-Valencia et al., 2016; Ferreira et al., 2016; Kruk et al., 2017), which is essential for ichthyofauna conservation.

The Upper Parana is one of the most dammed basins in the world (Agostinho et al., 2004) and suffers from the cumulative effects of changes in land use, pollution and nonnative species (Agostinho et al., 2008). With at least 150 large dams (Stevaux et al., 2009), the Upper Paraná is the most impounded and studied basin in the Neotropical region (Agostinho et al., 2008). However, little is known about the long-term effects of damming on fish $\alpha$ and $\beta$ diversity. Especially in reservoirs with nonregulated tributaries that can play the role of source areas (Nunes et al., 2015; Angulo-Valencia et al., 2016; Ferreira et al., 2016), such information is important because it can support management decisions in order to conserve those tributaries.

The goal of this study was to evaluate the long-term effects of damming on the ichthyofauna structure of a large reservoir with tributaries with little or no regulation by assessing the $\alpha$ and $\beta$ diversity trends of its fish assemblages over a period of 14 years. We expected that, due the presence of preserved tributaries with natural flood regimes, the tendency for $\alpha$ diversity to decrease and for $\beta$ diversity to increase would be reduced, possibly minimizing the impact of damming on the fish assemblages.

\section{Materials and methods}

\subsection{Study area}

The Paraná River is ranked 10th in water discharge in the world and is the second largest drainage basin of South America (Stevaux et al., 1997). The Upper Paraná comprises the upper third of the basin (Abell et al., 2008), with an area of $891,000 \mathrm{~km}^{2}, 10.5 \%$ of the total area of Brazil (Agostinho et al., 2008). It represents the upstream stretch above Sete Quedas Falls, which was flooded during the filling of the Itaipu Reservoir in 1982. This event induced a massive invasion of fish species from the Lower Paraná River (Júlio Jr. et al., 2009), resulting in biotic homogenization (Vitule et al., 2012). The Porto Primavera Reservoir is located on an alluvial floodplain in the Upper Paraná River, southeastern Brazil (Fig. 1). It was built for hydroelectric power generation and became operational in March 1999. With a length of $10,186 \mathrm{~m}$, it is the longest dam in Brazil. The dam has a pool-weir-orifice fish passage (Makrakis et al., 2007; Wagner et al., 2012). The reservoir was filled in two stages; the first (elevation of $253 \mathrm{~m}$ ) was completed in December 1998, and the second (elevation of $257 \mathrm{~m}$ ) was completed in March 2001. The power plant operates in a run-of-the-river system with very small variations in the water level $(<0.4 \mathrm{~m})$ and a long-term average discharge of $6981 \mathrm{~m}^{3} \cdot \mathrm{s}^{-1}$, with an average water residence time of 33.9 days. Based on area, Porto Primavera is the largest reservoir in the Paraná basin, with a length of $270 \mathrm{~km}$, a surface area of $2040 \mathrm{~km}^{2}$ and an average depth of $6.8 \mathrm{~m}$; in addition, it drains a basin of $572,480 \mathrm{~km}^{2}$ (Shibatta \& Dias, 2006).

There are four major tributaries with low-level or no regulation that flow into the reservoir (Fig. 1). The Verde River (draining a basin of $24,184 \mathrm{~km}^{2}$; average discharge of $222 \mathrm{~m}^{3} \cdot \mathrm{s}^{-1}$ ) and the Pardo River $\left(39,419 \mathrm{~km}^{2} ; 359 \mathrm{~m}^{3} \cdot \mathrm{s}^{-1}\right)$ are on the right bank, and the Aguapeí River $\left(13,196 \mathrm{~km}^{2} ; 98 \mathrm{~m}^{3} \cdot \mathrm{s}^{-1}\right)$ and the Peixe River are on the left bank $\left(10,769 \mathrm{~km}^{2} ; 84 \mathrm{~m}^{3} \cdot \mathrm{s}^{-1}\right)$.

\subsection{Samplings and data analysis}

Quarterly samplings were performed at four locations (Fig. 1) from 1999 to 2012 (the coordinates and description of each site are presented in Table S1). The data from 2002 and 2010 were not used due to a lack of sampling standardization. Fish were collected with gillnets (30-to-200 mm mesh, see Table S2 for a detailed description of the fishing gear) set for $24 \mathrm{~h}$ at each sampling site.

Based on the abundance matrix of the individuals collected by each sampling, the catch per unit effort (CPUE) was generated from the number of individuals captured per $1000 \mathrm{~m}^{2}$ of gillnet set for $24 \mathrm{~h}$. The CPUE data were $\log _{10}$ transformed to meet the assumptions of the parametric tests. All statistical analyses were performed using $R(R$ Development Core Team, 2016). From the CPUE matrix grouped annually, we calculated the Shannon-Wiener $\left(\mathrm{H}^{\prime}\right)$ diversity index according to Magurran (2004). To standardize efforts across samplings, we used the rarefy function from the vegan package (Oksanen et al., 2016) to calculate species richness.

To assess the temporal trend in $\alpha$ diversity (using the rarefied species richness and Shannon-Wiener index as measures), abundance $\left(\log _{10}\right.$ CPUE) and $\beta$ diversity, we used ordinary least squares (OLS) regressions (Magurran et al., 2015). The $\beta$ diversity assesses the homogenization process (Magurran et al., 2015) and was measured as the Sørensen dissimilarity and its turnover component (Baselga, 2010), which were both calculated in relation to the first year of impoundment (1999) using the beta.pair function in the betapart package (Baselga \& Orme, 2012). Next, we used the beta.multi-function from the betapart package to compute, for each year, the Sørensen dissimilarity for all sites. To verify differences in the trends among sites, the regressions were performed for each sampling site. Furthermore, we analyzed the trends in $\alpha$ diversity for the native and nonnative species separately.

For the temporal and spatial variance of the rarefied species richness, Shannon-Wiener index and abundance ( $\log _{10}$ CPUE), we 


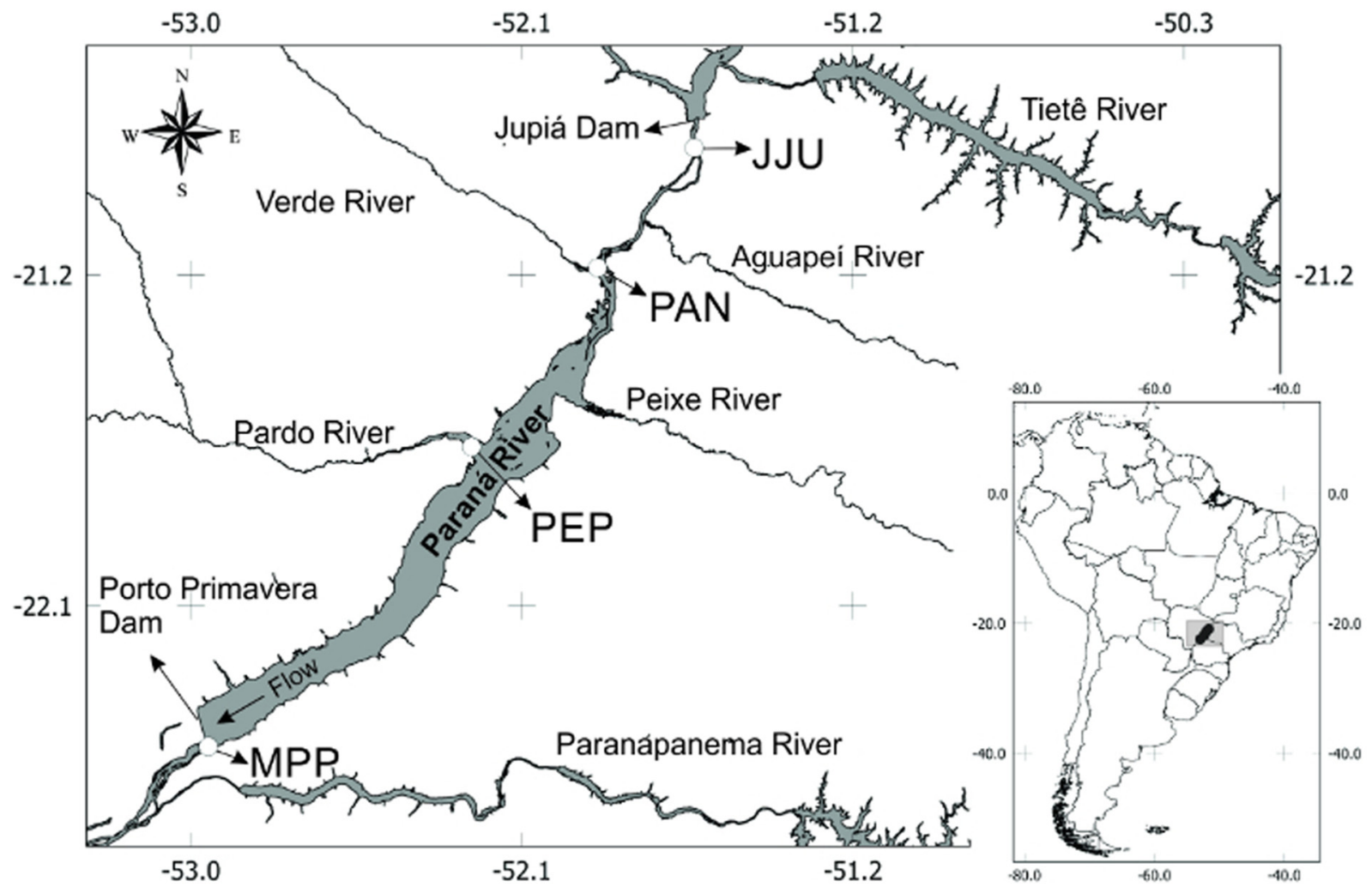

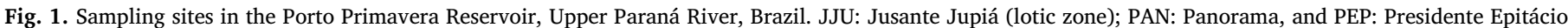
(transition zone); and MPP: Montante Porto Primavera (lentic zone).

performed analysis of variance (one-way ANOVA) using the attributes as the response variables. We considered the sampling sites as replicates of the explanatory variable (sampling years) in the temporal assessment and the sampling years as replicates of the explanatory variable (sampling sites) in the spatial assessment. For pairwise comparisons, when ANOVA presented a significant difference at a significance level of $p<0.05$, we performed a post hoc analysis of pairwise comparisons among the factors (e.g., the sampling sites in the spatial assessment) using Fisher's least significant difference (LSD).

We quantified the differences in the fish assemblages among the sampling sites using nonmetric multidimensional ordination (NMDS). For this, we used the R function metaMDS in the vegan package (Dixon, 2003) with the Bray-Curtis dissimilarity index. This analysis is recommended for community ordination, which runs NMDS multiple times with randomization, compares all results, and stops after finding a similar minimum stress solution twice (Oksanen et al., 2016). After the ordination, we used a multiple response permutation procedure (MRPP, McCune \& Grace (2002)) based on Euclidean distance with 999 permutations to assess whether the sampling sites demonstrated significant clustering in two-dimensional NMDS space (mrpp function, vegan package).

To quantify the variance of the fish assemblage structure in the sampling sites (also a measure of $\beta$ diversity, as described by Anderson et al. (2006)), we used the betadisper function, with Bray-Curtis distance, from the vegan package (Oksanen et al., 2016). To test if there were differences in the variance among sites, a permutation test (permutest function with 999 permutations, vegan package) was performed, including pairwise comparisons. This test permutes the model residuals from betadisper to generate a permutation distribution of $\mathrm{F}$, considering the null hypothesis of no difference in the dispersions among groups.

\section{Results}

A total of 30,731 individuals were captured, which were distributed in six orders, 23 families and 79 taxa (Table S3). Characiformes and Siluriformes were the most abundant orders, with 34 (43\%) and 33 (42\%) species, respectively. The other orders were Perciformes, which had seven species (9\%), Gymnotiformes, which had three species (4\%), and Pleuronectiformes and Myliobatiformes, which had one (1\%) species each. Native species predominated, with 46 species (58.2\%), while 24 species $(30.3 \%)$ were nonnative and nine $(12.6 \%)$ taxa were identified only to the genus level.

After the reservoir formation, five species that had not been found between the two filling periods (1999-2001) were recorded: the nonnative species Geophagus proximus, Hemiodus orthonops, Cichla piquiti and Triportheus nematurus and the native species Salminus hilarii. The other 20 nonnatives species had been present before 2001 . Similarly, 13 species present in the early years, from 1999 to 2001, were not caught after 2009 (Roeboides descalvadensis, Leporinus striatus, Rhinodoras dorbignyi, Hypostomus sp.4, Pimelodella sp.1, Moenkhausia intermedia, Astyanax sp., Hypostomus ancistroides, Hypostomus sp.4, Callichthys callichthys, Eigenmannia trilineata, Hoplerythrinus unitaeniatus, and Parodon nasus in decreasing order of abundance). Of these, only $R$. descalvadensis was among the 30 most abundant species in the filling period. 

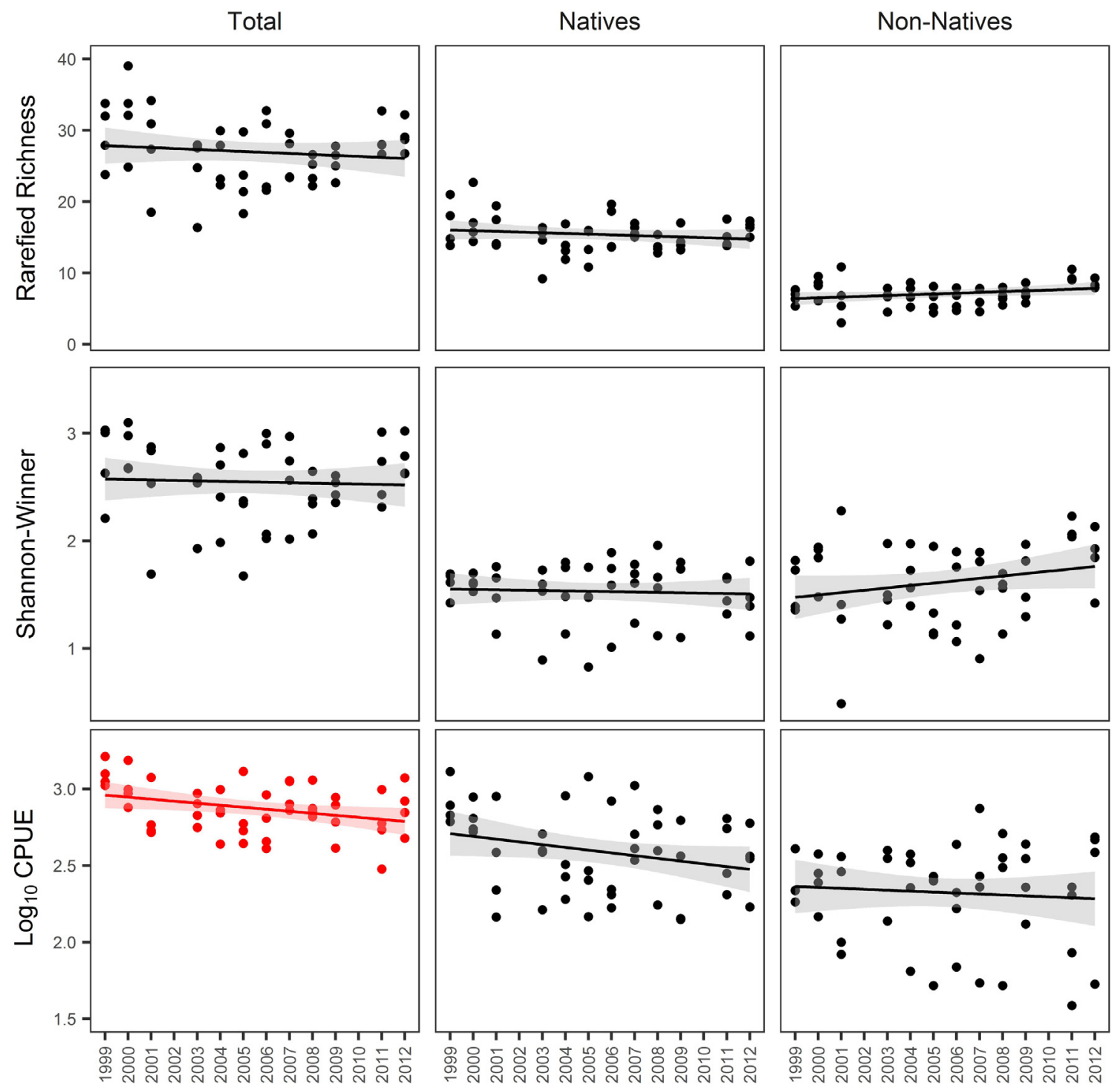

Fig. 2. Temporal trends in $\alpha$ diversity (rarefied species richness and Shannon-Wiener index) and abundance (top, middle, and bottom panels, respectively), considering all native and nonnative species (left, middle and right panels, respectively) in the Porto Primavera Reservoir, Upper Paraná River, Brazil. Trend lines (OLS regression) are color-coded red if significantly positive $(p<0.05, n=12)$ and black if not significant (there were no significantly negative slopes). See Table S4 for the regression parameters. (For interpretation of the references to color in this figure legend, the reader is referred to the web version of this article.)

There was no decreasing trend in $\alpha$ diversity over the 14 years of sampling (Fig. 2, regression parameters in Table S4). Despite the decreasing trend in total abundance (OLS regression, $\mathrm{r}^{2}=0.11, p=0.02$, $n=48$ ), there was no significant decreasing trend in native and nonnative richness (Fig. 2; regression parameters in Table S4). When analyzed by site, the $\alpha$ diversity showed an increasing trend in nonnative richness at the MPP site (lacustrine) $\left(\mathrm{r}^{2}=0.40, p=0.03, n=12\right)$, whereas the other sites showed no trend for any group (i.e., total, native and nonnative richness; Fig. S1 and regression parameters in Table S5).

Regarding the homogenization process, there was an increasing trend in the Sørensen dissimilarity $\left(\mathrm{r}^{2}=0.44, p=0.026, n=11\right)$ and in the species turnover $\left(\mathrm{r}^{2}=0.66, p=0.002, \mathrm{n}=11\right)$ relative to the initial year only in the lacustrine site, MPP. Likewise, there was no overall (considering all sampling sites) trend in both Sørensen dissimilarity and species turnover in the reservoir (Fig. 3; regression parameters in Table S6). In addition, there was no significant trend in the Sørensen dissimilarity across the sampling sites $\left(\mathrm{r}^{2}=0.01, p=0.80\right.$, $\mathrm{n}=12$; Fig. 4).

The comparison among years also revealed no difference for the rarefied richness (ANOVA, DF $=11 ; \mathrm{F}=1.46 ; p=0.19$ ), the Shannon-
Wiener index (ANOVA, DF $=11 ; \mathrm{F}=0.83 ; p=0.61$ ) and the abundance (ANOVA, $\mathrm{DF}=11 ; \mathrm{F}=1.93 ; p=0.07$ ) values (Fig. S2). Regarding the spatial assessment, the lacustrine site (MPP) showed smaller richness (ANOVA, DF $=3 ; \mathrm{F}=6.68 ; p<0.001$ ) and ShannonWiener index (ANOVA, DF $=3 ; \mathrm{F}=4.06 ; p=0.005$ ) values, while the riverine site (JJU) showed the highest abundance value (ANOVA, $\mathrm{DF}=3 ; \mathrm{F}=4.06 ; p=0.012$ ) (Fig. S3).

Regarding the fish assemblage structure, there were differences among the sampling sites (i.e., significant clustering, MRPP, A $=0.206$, $p=0.001$ ), as shown by the NMDS ordination (stress $=0.19$; Fig. 5). Moreover, there were differences in the fish assemblage variance (permutest, $\mathrm{F}=4.76, p=0.004$ ), with a higher variation (i.e., higher temporal $\beta$ diversity) at the lacustrine site than at the other sites (Fig. 5 and Fig. S4).

\section{Discussion}

In spite of the inherent impact of this damming, including the impacts downstream (Agostinho et al., 2004; Sanches et al., 2006; Agostinho et al., 2009; Vasconcelos et al., 2014), the temporal 


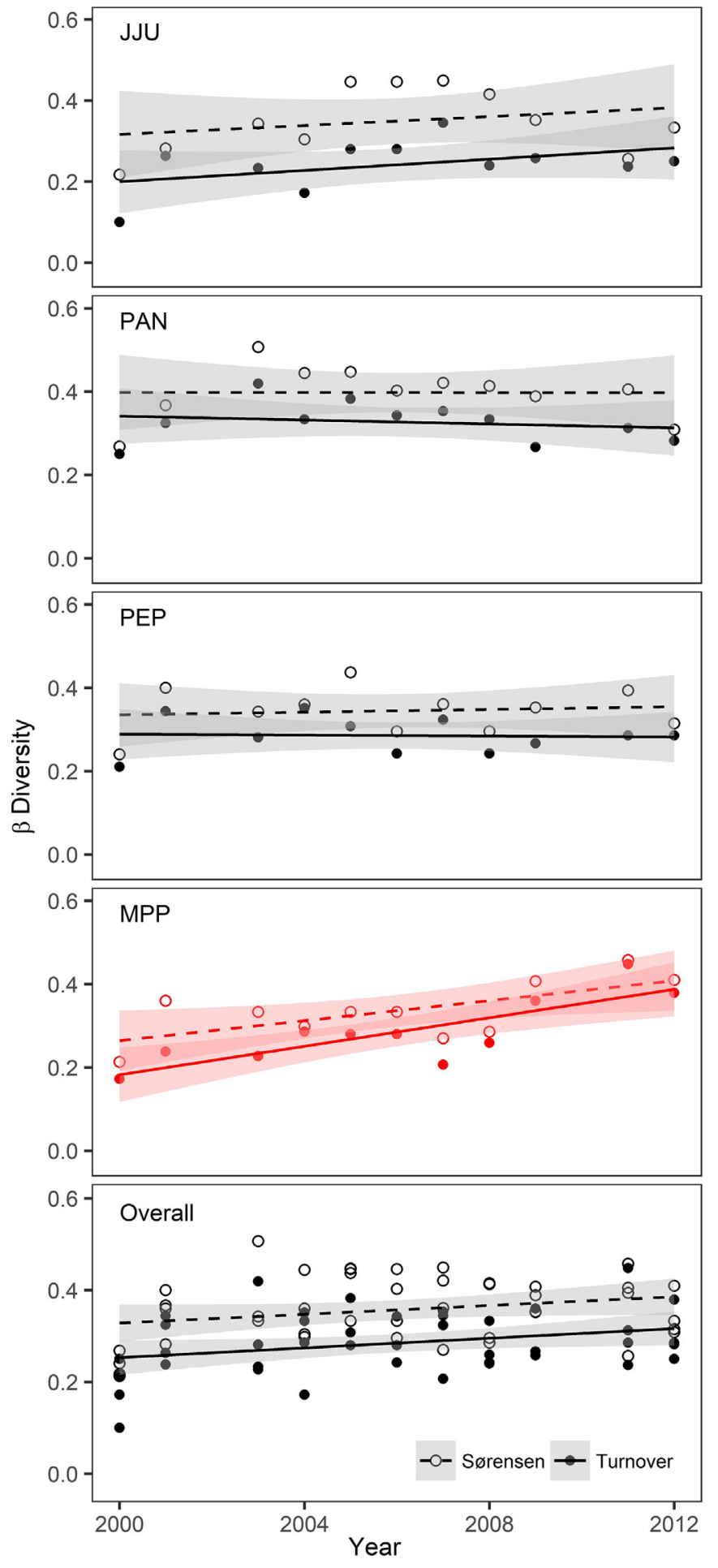

Fig. 3. Temporal trends in $\beta$ diversity (Sørensen dissimilarity and turnover, relative to the initial year) for each site and all sites over the first 14 years of the Porto Primavera Reservoir, Upper Paraná River, Brazil. Trend lines (OLS regression) are color-coded red if significantly positive ( $\mathrm{p}<0.05, n=11$ ) and black if not significant (there were no significantly negative slopes). See Table S6 for the regression parameters. (For interpretation of the references to color in this figure legend, the reader is referred to the web version of this article.)

variations in the fish fauna of the Porto Primavera Reservoir presented different attributes than those of the other reservoirs in the Neotropical region. Generally, over the aging process of Neotropical reservoirs, there is a decreasing trend in $\alpha$ diversity (Agostinho et al., 1999;

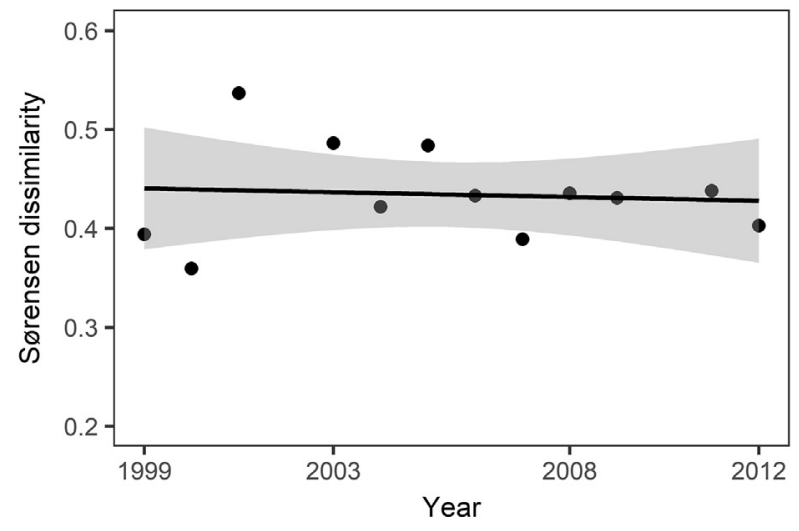

Fig. 4. $\beta$ diversity (Sørensen dissimilarity) across all sites over the first 14 years of the Porto Primavera Reservoir, Upper Paraná River, Brazil. There was no significant trend (OLS regression, $\mathrm{r}^{2}=0.01, p=0.80, \mathrm{n}=12$ ).

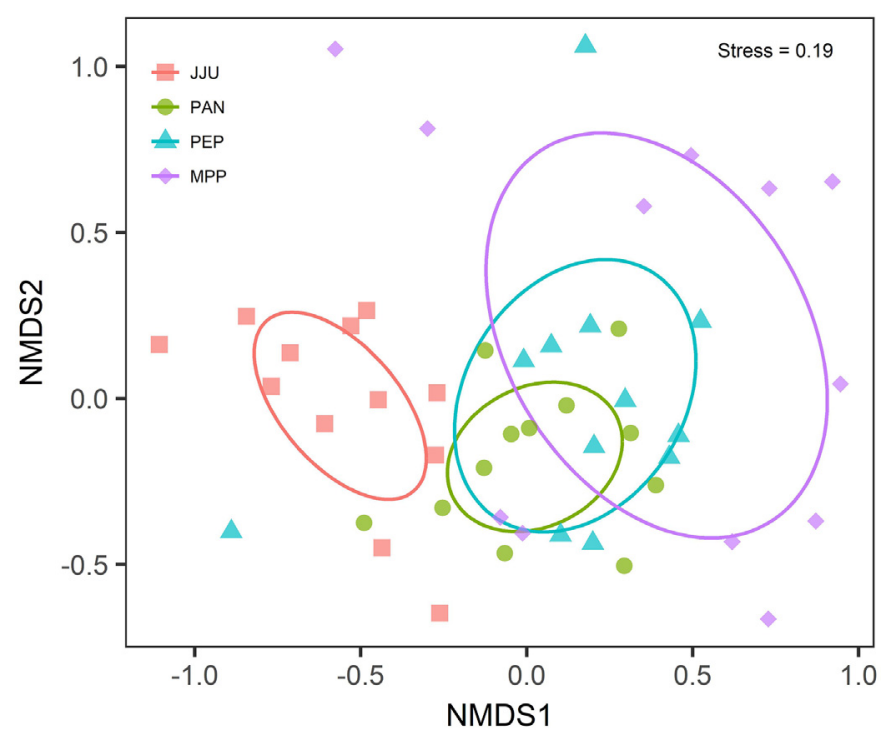

Fig. 5. Nonmetric multidimensional scaling (NMDS) plot showing the distribution of each sampling year for the sampling sites (JJU: Jusante Jupiá; PAN: Panorama; PEP: Presidente Epitácio; MPP: Montante Porto Primavera) in the Porto Primavera Reservoir, Upper Paraná River, Brazil. The group means and the within-group covariance define the centroid and the shape of each dispersion ellipse, respectively.

Agostinho et al., 2008) and abundance (Petrere Jr, 1996). Assessing the first 14 years of Porto Primavera, we found no significant decreasing tendency in the $\alpha$ diversity measures, and, despite a decreasing trend in the total abundance, there was no decreasing trend in the number of native species. Furthermore, the comparison among years showed no difference in $\alpha$ diversity or abundance. Likewise, the expected homogenization of the fish assemblage in the reservoir (Poff et al., 2007; Petesse \& Petrere Jr, 2012; Daga et al., 2014) did not occur as an overall trend, as shown by the $\beta$ diversity relative to the initial year and the changes in $\beta$ diversity across the sampling sites in the study. Except for the MPP site, the assemblage composition of each site showed no increasing trend in the temporal turnover relative to that of the initial year, unlike what is typical for other assemblages after disturbances (Dornelas et al., 2014; Magurran et al., 2015). The result observed at MPP was expected, since this site is located at a lacustrine stretch of the reservoir, where the impacts of dams are likely to be higher than those at the other sites.

The Porto Primavera Reservoir maintained high species richness, with 79 species sampled during this study, which corresponded to $25 \%$ of the fish fauna registered by Langeani et al. (2007) for the whole 
Upper Paraná Basin. This richness is also higher than the average number of species (30) in 77 Brazilian reservoirs (Agostinho et al., 2007) but is consistent with some of the predictions based on the species-area relationship (Eadie et al., 1986; Albert \& Reis, 2011), since Porto Primavera is a large reservoir. Another singularity of the Porto Primavera Reservoir is the presence of 17 long-distance migratory species (Table S3). Agostinho et al. (2007) noted in a survey of 77 Brazilian reservoirs that only $5 \%$ of the reservoirs hosted more than three long-distance migratory species, and in $>50 \%$ there were no migratory species. On the other hand, the high number of nonnative species (24) in the reservoir could in part be explained by the flooding of Sete Quedas falls after the Itaipu reservoir was filled in 1982, a natural barrier between the Lower and Upper Paraná ecoregions (Abell et al., 2008). After the flooding, 33 species from the Lower Paraná River colonized the Upper Paraná (Júlio Jr. et al., 2009), resulting in the homogenization of the two assemblages (Vitule et al., 2012). Hence, a considerable homogenization process occurred decades before the creation of the Porto Primavera Reservoir, and this process may still be ongoing due to the effects of damming and other factors, such as the growing exploitation of aquaculture in the river basin. Of the 24 nonnative species reported in this study, 14 are from the Lower Paraná and have been observed since the early years of the reservoir. Only four nonnative species arrived after the filling phase, and of those, one $(H$. orthonops) is also from the Lower Paraná (Agostinho et al., 2015). Additionally, after the reservoir formation, three new nonnative and one new native species were registered: G. proximus, C. piquiti, and T. nematurus (nonnative) and $S$. hilarii (native). Despite being first recorded in Porto Primavera in 2003, G. proximus has become one of the most abundant species in the reservoir. Furthermore, number of species, 13, that were not observed after the second stage of reservoir filling (2001) is low compared with that determined by a long-term evaluation of another large reservoir in the same basin, where 27 out of 50 species disappeared (Orsi \& Britton, 2014).

When reservoirs are formed, an increase in primary production is expected, resulting in an early increase in fish abundance (Petrere $\mathrm{Jr}$, 1996; Agostinho et al., 1999; Agostinho et al., 2008). However, these trends were not observed in the Porto Primavera Reservoir, possibly due to two related factors. The first is the run-of-the-river operation system, which attenuates the flood pulses, which are especially important events for migratory species due to the seasonal increase in trophic resources and the connectivity with floodplains that provide recruitment areas (Petrere Jr, 1983; Alvim \& Peret, 2004). The other factor is the low residence time of the water, which is common in runof-river systems and intensifies the flushing of autochthonous organic matter, hence reducing nutrient availability and restricting primary production (Kimmel \& Groeger, 1984). Porto Primavera also inundated extensive floodplains and reduced nursery sites (e.g., lateral lagoons), which may cause the loss of abundance and $\alpha$ diversity. Nevertheless, there was neither a decreasing trend in overall $\alpha$ diversity (both rarefied richness and Shannon-Wiener) nor a decreasing trend in species richness in the sampling sites, including for the native species.

A consistent explanation for this singularity is the role of the tributaries as spawning and early development sites for native species. There were at least nine migratory species (Brycon orbignyanus, Hemisorubim platyrhynchos, Pimelodus maculatus, Pimelodus ornatus, Prochilodus lineatus, Pseudoplatystoma corruscans, Rhaphiodon vulpinus, Salminus brasiliensis and Sorubim lima) in the reservoir that also occur in the reservoir tributaries at some stage of early development (da Silva et al., 2015). Beyond the migratory species, at least 24 nonmigratory species have also been registered among the ichthyoplankton of these tributaries (da Silva et al., 2011; Makrakis et al., 2012; Lima et al., 2013). These numbers will be higher once several taxa in these studies are not identified beyond the genus level, as is the case of the species of the genus Megaleporinus.

Fish reproduction is affected by impoundments, regardless of reproductive strategy (Angulo-Valencia et al., 2016), and most fish species, even sedentary ones, show some degree of dependence on riverine stretches (Agostinho et al., 2008; Angulo-Valencia et al., 2016; Miranda \& Dembkowski, 2016). Thus, the presence of tributaries with little nor no regulation in reservoirs is important for the maintenance of habitats (Eadie et al., 1986) and fish diversity (Agostinho et al., 2004; Hoffmann et al., 2005; Agostinho et al., 2007; Angulo-Valencia et al., 2016; Ferreira et al., 2016). In addition, they can act as source habitats (Pulliam, 1988; Pulliam \& Danielson, 1991; Dias, 1996), minimizing the effects of river impoundments on the homogenization of local and regional fish faunas.

The overall $\beta$ diversity analyses, relative to those of the initial year, showed no significant increasing trend, which is corroborated by the changes in $\beta$ diversity across the study sites. When the sites were analyzed separately, there was an expected significant increasing trend in the $\beta$ diversity of the lacustrine site (MPP), since it was the site most impacted by the impoundment (Figs. 3, 5, S1, S3 and S4). On the other hand, in the sites near the tributary mouths (PAN and PEP), there was no increasing trend. In this way, despite the expected homogenization occurring in the lacustrine zone, the presence of the tributaries seemed to minimize this general homogenization trend. It is noteworthy that, although PEP site has lacustrine characteristics (see Fig. 1 and description in Table S1), it presented a $\beta$ diversity trend more similar to that of PAN site than that of MPP site, probably due the presence of the tributary.

We attribute the pattern of temporal variation in $\alpha$ and $\beta$ diversity at the Porto Primavera Reservoir to probable source-sink demographic dynamics (Hansen, 2011), with the tributaries as the source areas (da Silva et al., 2011; Makrakis et al., 2012; Lima et al., 2013; da Silva et al., 2015) and the reservoir itself as the sink. In this way, the Upper Paraná fish assemblages fit the concept of a metacommunity (Leibold et al., 2004) that provides stability to all ichthyofauna (Mellin et al., 2014), minimizing the expected trend towards biotic homogenization (Petesse \& Petrere Jr, 2012; Daga et al., 2014). The source-sink model is suitable to explain the dynamics of Neotropical migratory fish that select different habitats for different stages of their life cycles (Agostinho et al., 2003; Godinho \& Kynard, 2009). Therefore, tributaries that function as nursery sites must be protected, since they act as source areas for population maintenance (Hansen, 2011; Nunes et al., 2015; Angulo-Valencia et al., 2016; Ferreira et al., 2016).

Furthermore, there are large banks of macrophytes in the reservoir (Pitelli et al., 2014), increasing the habitat heterogeneity in the region between the PAN and PEP sites. The $\beta$ diversity demonstrated low variation in the assemblage structure of this area. Likewise, the existence of riverine stretches in upstream reservoirs, such those in Porto Primavera, can minimize the impacts of impoundment on migratory species (Gubiani et al., 2010; Miranda \& Dembkowski, 2016), which also contributes to the maintenance of fish diversity. In this way, beyond the tributary floodplains, the riverine zones and the macrophytes contribute to the structural complexity of the environment, favoring biological diversity and fish assemblage stability in this reservoir.

Due to the growing demand for new hydroelectric enterprises, the stakeholders should analyze the new impoundments projects in a basinscale context, considering the maintenance of ecosystem services and the conservation of biodiversity (Winemiller et al., 2016). According to our results, which are consistent with a vast body of literature (Ponton et al., 2000; Oliveira et al., 2004; da Silva et al., 2015; Nunes et al., 2015; Angulo-Valencia et al., 2016; Ferreira et al., 2016; Kruk et al., 2017), we highly stress the importance of tributaries for the maintenance of the fish assemblages diversity in reservoirs. Thus, keeping tributaries non regulated and conserved is an important tool for diversity maintenance and should be considered in further impoundment projects in reservoir tributaries (Pompeu, 2012). In the same way, it is imperative to maintain strict control on other harmful activities, such as irregular land use, aquaculture, fishing and clay mining, as well as to adopt actions in order to improve the use, management and policies of natural resources (Pelicice et al., 2017). This should guide 
environmental management programs in reservoirs in the Neotropical region, as it allows the balance between electricity production and the conservation of fish diversity.

Supplementary data to this article can be found online at https:// doi.org/10.1016/j.biocon.2018.05.027.

\section{References}

Abell, R., Thieme, M.L., Revenga, C., Bryer, M., Kottelat, M., Bogutskaya, N., ... Bussing, W., 2008. Freshwater ecoregions of the world: a new map of biogeographic units for freshwater biodiversity conservation. Bioscience 58 (5), 403-414.

Agostinho, A.A., Miranda, L.E., Bini, L.M., Gomes, L.C., Thomaz, S.M., Suzuki, H.I., 1999. Patterns of colonization in neotropical reservoirs, and prognoses on aging. In: Tundisi, J.G., Straskraba, M. (Eds.), Theoretical reservoir ecology and its applications. International Institute of Ecology (IIE), São Carlos, pp. 227-265.

Agostinho, A.A., Gomes, L.C., Suzuki, H.I., Júlio Jr., H.F., 2003. Migratory fishes of the Upper Paraná River basin, Brazil. In: Carolsfeld, J., Harvey, B., Ross, C., Baer, A. (Eds.), Migratory Fishes of South America: Biology, Fisheries and Conservation Status. World Fisheries Trust: The World Bank: International Development Research Centre, Ottawa, pp. 19-98.

Agostinho, A.A., Gomes, L.C., S., V., Okada, E.K., 2004. Flood regime, dam regulation and fish in the Upper Paraná River: effects on assemblage attributes, reproduction and recruitment. Rev. Fish Biol. Fish. 14, 11-19. http://dx.doi.org/10.1007/s11160-0043551-y.

Agostinho, A.A., Gomes, L.C., Pelicice, F.M., 2007. Ecologia e manejo de recursos pesqueiros em reservatórios do Brasil. EDUEM, Maringá, PR.

Agostinho, A.A., Pelicice, F.M., Gomes, L.C., 2008. Dams and the fish fauna of the Neotropical region: impacts and management related to diversity and fisheries. Braz. J. Biol. 68 (4 Suppl), 1119-1132. http://dx.doi.org/10.1590/S151969842008000500019.

Agostinho, A.A., Bonecker, C.C., Gomes, L.C., 2009. Effects of water quantity on connectivity: the case of the upper Paraná River floodplain. Ecohydrol. Hydrobiol. 9 (1), 99-113. http://dx.doi.org/10.2478/v10104-009-0040-x.

Agostinho, A.A., Suzuki, H.I., Fugi, R., Alves, D.C., Tonella, L.H., Espindola, L.A., 2015. Ecological and life history traits of Hemiodus orthonops in the invasion process: looking for clues at home. Hydrobiologia 746 (1), 415-430. http://dx.doi.org/10. 1007/s10750-014-2030-2.

Agostinho, A.A., Gomes, L.C., Santos, N.C.L., Ortega, J.C.G., Pelicice, F.M., 2016. Fish assemblages in Neotropical reservoirs: colonization patterns, impacts and management. Fish. Res. 173, 26-36. http://dx.doi.org/10.1016/j. fishres.2015.04.006.

Albert, J.S., Reis, R.E., 2011. Historical Biogeography of Neotropical Freshwater Fishes. Univ of California Press, Berkeley, CA.

Alvim, M.C.C., Peret, A.C., 2004. Food resources sustaining the fish fauna in a section of the upper São Francisco River in Três Marias, MG, Brazil. Braz. J. Biol. 64 (2), 195-202. http://dx.doi.org/10.1590/S1519-69842004000200003.

Anderson, M.J., Ellingsen, K.E., Mcardle, B.H., 2006. Multivariate dispersion as a measure of beta diversity. Ecol. Lett. 9 (6), 683-693. http://dx.doi.org/10.1111/j.1461-0248. 2006.00926.x.

Angulo-Valencia, M.A., Agostinho, A.A., Suzuki, H.I., da Luz-Agostinho, K.D.G., Agostinho, C.S., 2016. Impoundments affect fish reproduction regardless of reproductive strategy. Lakes Reserv. Res. Manag. 21 (4), 362-374. http://dx.doi.org/ 10.1111/lre.12151.

Baselga, A., 2010. Partitioning the turnover and nestedness components of beta diversity. Glob. Ecol. Biogeogr. 19 (1), 134-143. http://dx.doi.org/10.1111/j.1466-8238.2009. 00490.x.

Baselga, A., Orme, C.D.L., 2012. Betapart: an R package for the study of beta diversity. Methods Ecol. Evol. 3 (5), 808-812. http://dx.doi.org/10.1111/j.2041-210X.2012. 00224.x.

Daga, V.S., Skóra, F., Padial, A.A., Abilhoa, V., Gubiani, E.A., Vitule, J.R.S., 2014. Homogenization dynamics of the fish assemblages in Neotropical reservoirs: comparing the roles of introduced species and their vectors. Hydrobiologia 746 (1), 327-347. http://dx.doi.org/10.1007/s10750-014-2032-0.

Dias, P.C., 1996. Sources and sinks in population biology. Trends Ecol. Evol. 11 (8), 326-330. http://dx.doi.org/10.1016/0169-5347(96)10037-9.

Dixon, P., 2003. VEGAN, a package of R functions for community ecology. J. Veg. Sci. 14 (6), 927-930. http://dx.doi.org/10.1111/j.1654-1103.2003.tb02228.x.

Dornelas, M., Gotelli, N.J., McGill, B., Shimadzu, H., Moyes, F., Sievers, C., Magurran, A.E., 2014. Assemblage time series reveal biodiversity change but not systematic loss. Science 344, 4. http://dx.doi.org/10.1126/science.1248484.

Eadie, J.M., Hurly, T.A., Montgomerie, R.D., Teather, K.L., 1986. Lakes and rivers as islands: species-area relationships in the fish faunas of Ontario. Environ. Biol. Fish 15 (2), 81. http://dx.doi.org/10.1007/bf00005423.

Ferreira, D.G., Souza-Shibatta, L., Shibatta, O.A., Sofia, S.H., Carlsson, J., Dias, J.H.P., ... Makrakis, M.C., 2016. Genetic structure and diversity of migratory freshwater fish in a fragmented Neotropical river system. Rev. Fish Biol. Fish. 1-23. http://dx.doi.org/ 10.1007/s11160-016-9441-2.

Gido, K.B., Matthews, W.J., Wolfinbarger, W.C., 2000. Long term changes in a reservoir fish assemblage: stability in an unpredictable environment. Ecol. Appl. 10 (5), 1517-1529. http://dx.doi.org/10.1890/1051-0761(2000)010[1517:LTCIAR]2.0. $\mathrm{CO} ; 2$.

Godinho, A.L., Kynard, B., 2009. Migratory fishes of Brazil: life history and fish passage needs. River Res. Appl. 25 (6), 702-712. http://dx.doi.org/10.1002/rra.1180.

Gubiani, E.A., Gomes, L.C., Agostinho, A.A., Baumgartner, G., 2010. Variations in fish assemblages in a tributary of the upper Paraná River, Brazil: a comparison between pre and post-closure phases of dams. River Res. Appl. 26 (7), 848-865. http://dx.doi. org/10.1002/rra.1298.

Hansen, A.J., 2011. Contribution of source-sink theory to protected area science. In: Liu, J., Hull, V., Morzillo, A.T., Wiens, J.A. (Eds.), Sources, Sinks, and Sustainability across Landscapes. Cambridge University Press, pp. 339-360.

Hoffmann, A.C., Orsi, M.L., Shibatta, O.A., 2005. Diversidade de peixes do reservatório da UHE Escola Engenharia Mackenzie (Capivara), Rio Paranapanema, bacia do alto rio Paraná, Brasil, e a importância dos grandes tributários na sua manutenção. Iheringia. Série Zoologia 95 (3). http://dx.doi.org/10.1590/s0073-47212005000300012.

Júlio Jr., H.F., Tós, C.D., Agostinho, Â.A., Pavanelli, C.S., 2009. A massive invasion of fish species after eliminating a natural barrier in the upper rio Paraná basin. Neotropical Ichthyology 7 (4), 709-718. http://dx.doi.org/10.1590/s167962252009000400021.

Kimmel, B.L., Groeger, A.W., 1984. Factors controlling primary production in lakes and reservoirs: a perspective. Lake and Reservoir Management 1 (1), 277-281. http://dx. doi.org/10.1080/07438148409354524.

Kruk, A., Ciepłucha, M., Zięba, G., Błońska, D., Tybulczuk, S., Tszydel, M., ... Penczak, T., 2017. Spatially diverse recovery (1986-2012) of fish fauna in the Warta River, Poland: the role of recolonizers' availability after large-area degradation. Ecol. Eng. 102, 612-624. http://dx.doi.org/10.1016/j.ecoleng.2017.01.019.

Langeani, F., Castro, R.M.C., Oyakawa, O.T., Shibatta, O.A., Pavanelli, C.S., Casatti, L., 2007. Diversidade da ictiofauna do Alto Rio Paraná: composição atual e perspectivas futuras. Biota Neotropica 7 (3), 181-197. http://dx.doi.org/10.1590/S167606032007000300020.

Leibold, M.A., Holyoak, M., Mouquet, N., Amarasekare, P., Chase, J.M., Hoopes, M.F., ... Gonzalez, A., 2004. The metacommunity concept: a framework for multi-scale community ecology. Ecol. Lett. 7 (7), 601-613. http://dx.doi.org/10.1111/j.14610248.2004.00608.x.

Lima, A.F., Makrakis, M.C., Silva, P.S., V., A.A., Makrakis, S., Assumpção, L., ... Dias, J.H.P., 2013. Padrões de distribuição e ocorrência espaço-temporal de ovos e larvas de peixes nos rios Pardo e Anhanduí, bacia do alto rio Paraná, Brasil. Revista Brasileira de Biociências 11 (1), 7-13.

Magurran, A.E., 2004. Measuring Biological Diversity. Blackwell Publishing, Oxford, UK.

Magurran, A.E., Dornelas, M., 2010. Biological diversity in a changing world. Philos. Trans. R. Soc. Lond. Ser. B Biol. Sci. 365 (1558), 3593-3597. http://dx.doi.org/10. 1098/rstb.2010.0296.

Magurran, A.E., Henderson, P.A., 2010. Temporal turnover and the maintenance of diversity in ecological assemblages. Philos. Trans. R. Soc. Lond. Ser. B Biol. Sci. 365 (1558), 3611-3620. http://dx.doi.org/10.1098/rstb.2010.0285.

Magurran, A.E., Baillie, S.R., Buckland, S.T., Dick, J.M., Elston, D.A., Scott, E.M., ... Watt, A.D., 2010. Long-term datasets in biodiversity research and monitoring: assessing change in ecological communities through time. Trends Ecol. Evol. 25 (10), 574-582. http://dx.doi.org/10.1016/j.tree.2010.06.016.

Magurran, A.E., Dornelas, M., Moyes, F., Gotelli, N.J., Mcgill, B., 2015. Rapid biotic homogenization of marine fish assemblages. Nat. Commun. 6, 8405. http://dx.doi. org/10.1038/ncomms9405.

Makrakis, S., Makrakis, M.C., Wagner, R.L., Dias, J.H.P., Gomes, L.C., 2007. Utilization of the fish ladder at the Engenheiro Sergio Motta Dam, Brazil, by long distance migrating potamodromous species. Neotropical Ichthyology 5 (2), 197-204. http://dx. doi.org/10.1590/S1679-62252007000200014.

Makrakis, M.C., Da Silva, P.S., Makrakis, S., Lima, A.F., Assumpção, L., Paula, S., ... Dias, J.H.P., 2012. Spawning and nursery habitats of neotropical fish species in the tributaries of a regulated river. In: Pourali, K., Raad, V.N. (Eds.), Larvae: Morphology, Biology and Life Cycle. Nova Science Publishers, New York, pp. 153-166.

McCune, B., Grace, J.B., 2002. CHAPTER 24 MRPP (Multi-response Permutation Procedures) and Related Techniques. In: McCune, B., Grace, J.B. (Eds.), Analysis of Ecological Communities. MjM Software Design, Gleneden Beach, OR.

Mellin, C., Bradshaw, C.J.A., Fordham, D.A., Caley, M.J., 2014. Strong but opposing $\beta$ diversity-stability relationships in coral reef fish communities. Proc. Biol. Sci. 281 (1777), 20131993. http://dx.doi.org/10.1098/rspb.2013.1993.

Miranda, L.E., Dembkowski, D.J., 2016. Evidence for serial discontinuity in the fish Community of a Heavily Impounded River. River Res. Appl. 32 (6), 1187-1195. http://dx.doi.org/10.1002/rra.2936.

Nilsson, C., Reidy, C.A., Dynesius, M., Revenga, C., 2005. Fragmentation and flow regulation of the world's large river systems. Science 308 (5720), 405-408. http://dx. doi.org/10.1126/science.1107887.

Nunes, D.M.F., Magalhães, A.L.B., Weber, A.A., Gomes, R.l.Z., Normando, F.T., Santiago, K.B., ... Bazzoli, N., 2015. Influence of a large dam and importance of an undammed tributary on the reproductive ecology of the threatened fish matrinxã Brycon orthotaenia Günther, 1864 (Characiformes: Bryconidae) in southeastern Brazil. Neotropical Ichthyology 13 (2), 317-324. http://dx.doi.org/10.1590/1982-022420140084.

Oksanen, J., Blanchet, F.G., Friendly, M., Kindt, R., Legendre, P., Mcglinn, D., ... Wagner, H., 2016. Vegan: Community Ecology Package. R Package Version 2.4-1.

Olden, J.D., Poff, N.L., 2004. Clarifying biotic homogenization. Trends Ecol. Evol. 19 (6), 282-283. author reply 283-284. https://doi.org/10.1016/j.tree.2004.03.024.

Oliveira, E.F., Goulart, E., Minte-Vera, C.V., 2004. Fish diversity along spatial gradients in the Itaipu Reservoir, Parana, Brazil. Braz. J. Biol. 64 (3A), 447-458. http://dx.doi. org/10.1590/S1519-69842004000300008.

Orsi, M.L., Britton, J.R., 2014. Long-term changes in the fish assemblage of a neotropical hydroelectric reservoir. J. Fish Biol. 84 (6), 1964-1970. http://dx.doi.org/10.1111/ jfb.12392.

Pelicice, F.M., Azevedo-Santos, V.M., Vitule, J.R.S., Orsi, M.L., Lima Junior, D.P., Magalhães, A.L.B., ... Agostinho, A.A., 2017. Neotropical freshwater fishes imperilled by unsustainable policies. Fish Fish. http://dx.doi.org/10.1111/faf.12228. 
Petesse, M.L., Petrere Jr., M., 2012. Tendency towards homogenization in fish assemblages in the cascade reservoir system of the Tietê river basin, Brazil. Ecol. Eng. 48, 109-116. http://dx.doi.org/10.1016/j.ecoleng.2011.06.033.

Petrere Jr., M., 1983. Relationships among catches, fishing effort and river morphology for eight rivers in Amazonas state(Brazil), during 1976-1978. Amazoniana 8 (2).

Petrere Jr., M., 1996. Fisheries in large tropical reservoirs in South America. Lakes Reserv. Res. Manag. 2, 111-133. http://dx.doi.org/10.1111/j.1440-1770.1996. tb00054.x.

Pitelli, R.L.C.M., Pitelli, R.A., Rodrigues, C.J., Dias, J.H.P., 2014. Aquatic plant community in Porto Primavera Reservoir. Planta Daninha 32 (3), 467-473. http://dx.doi. org/10.1590/S0100-83582014000300001.

Poff, N.L., Olden, J.D., Merritt, D.M., Pepin, D.M., 2007. Homogenization of regional river dynamics by dams and global biodiversity implications. Proc. Natl. Acad. Sci. U. S. A. 104 (14), 5732-5737. http://dx.doi.org/10.1073/pnas.0609812104.

Pompeu, P.S., 2012. Rios de preservação permanente: uma alternativa para a conservação da ictiofauna? Ação Ambiental 13 (47), 12-14.

Ponton, D., Sylvie Mérigoux, S., Copp, G.H., 2000. Impact of a dam in the neotropics: what can be learned from young-of-the-year fish assemblages in tributaries of the Ri7er Sinnamary (French Guiana, South America)? Aquat. Conserv. Mar. Freshwat. Ecosyst. 10, 25-51.

Pulliam, H.R., 1988. Sources, sinks, and population regulation. Am. Nat. 132 (5), 652-661. http://dx.doi.org/10.1086/284880.

Pulliam, H.R., Danielson, B.J., 1991. Sources, sinks and habitat selection: a landscape perspective on population dynamics. Am. Nat. 137 (Supplement), 50-66.

R Development Core Team, 2016. R: A Language and Environment for Statistical Computing. Vienna, Austria. Retrieved from. https://www.R-project.org/.

Rahel, F.J., 2002. Homogenization of freshwater faunas. Annu. Rev. Ecol. Syst. 33 (1), 291-315. http://dx.doi.org/10.1146/annurev.ecolsys.33.010802.150429.

Říha, M., Kubečka, J., Vašek, M., Sed’a, J., Mrkvička, T., Prchalová, M., ... Tušer, M. 2009. Long-term development of fish populations in the Rímov reservoir. Fish. Manag. Ecol. 16 (2), 121-129. http://dx.doi.org/10.1111/j.1365-2400.2008. 00650.x.

Sanches, P.V., Nakatani, K., Bialetzki, A., Baumgartner, G., Gomes, L.C., Luiz, E.A., 2006. Flow regulation by dams affecting ichthyoplankton: the case of the Porto Primavera
Dam, Paraná River, Brazil. River Res. Appl. 22 (5), 555-565. http://dx.doi.org/10. 1002/rra.922.

Shibatta, O.A., Dias, J.H.P., 2006. 40 Peixes do Brasil. Doiis, Rio de Janeiro.

da Silva, P.S., Assumpção, L., Lima, A.F., Makrakis, M.C., Makrakis, S., Dias, J.H.P., 2011. Distribuição espacial e temporal de ovos e larvas de peixes no rio Aguapeí SP, alto rio Paraná. Forum Ambiental da Alta Paulista 7 (3), 462-478.

da Silva, P.S., Makrakis, M.C., Miranda, L.E., Makrakis, S., Assumpção, L., Paula, S., ... Marques, H., 2015. Importance of reservoir tributaries to spawning of migratory fish in the Upper Paraná River. River Res. Appl. 31 (3), 313-322. http://dx.doi.org/10. 1002/rra.2755.

Stevaux, J.C., Souza-Filho, E.E., Jabur, I.C., 1997. A história quaternária do rio Paraná em seu alto curso. In: Vazzoler, A.E.A.M., Agostinho, A.A., Hahn, N.S. (Eds.), A Planície de Inundação do Alto Rio Paraná. Aspectos físicos, biológicos e socioeconômicos. Maringá, EDUEM, pp. 47-72.

Stevaux, J.C., Martins, D.P., Meurer, M., 2009. Changes in a large regulated tropical river: the Paraná River downstream from the Porto primavera dam, Brazil. Geomorphology 113 (3-4), 230-238. http://dx.doi.org/10.1016/j.geomorph.2009.03.015.

Vasconcelos, L.P., Alves, D.C., Gomes, L.C., 2014. Fish reproductive guilds downstream of dams. J. Fish Biol. 85 (5), 1489-1506. http://dx.doi.org/10.1111/jfb.12501.

Vitule, J.R.S., Freire, C.A., Simberloff, D., 2009. Introduction of non-native freshwater fish can certainly be bad. Fish Fish. 10 (1), 98-108. http://dx.doi.org/10.1111/j. 1467-2979.2008.00312.x.

Vitule, J.R.S., Skóra, F., Abilhoa, V., 2012. Homogenization of freshwater fish faunas after the elimination of a natural barrier by a dam in Neotropics. Divers. Distrib. 18 (2), 111-120. http://dx.doi.org/10.1111/j.1472-4642.2011.00821.x.

Wagner, R.L., Makrakis, S., Castro-Santos, T., Makrakis, M.C., Dias, J.H.P., Belmont, R.F., 2012. Passage performance of long-distance upstream migrants at a large dam on the Paraná River and the compounding effects of entry and ascent. Neotropical Ichthyology 10 (4), 785-795. http://dx.doi.org/10.1590/S167962252012000400011.

Winemiller, K.O., McIntyre, P.B., Castello, L., Fluet-Chouinard, E., Giarrizzo, T., Nam, S., ... Saenz, L., 2016. Development and Environment. Balancing hydropower and biodiversity in the Amazon, Congo, and Mekong. Science 351 (6269), 128-129. http:// dx.doi.org/10.1126/science.aac7082. 